A DESPATCH from Hàvana, dated August I9, states that late advices from Lima and Peru report a serious accident had occurred sixty miles from that city. $A$ body of earth, estimated at $10,000,000$ cubic yards, fell from a mountain side into a valley, severely injuring a number of persons, and damming up a river, the water of which had risen 109 feet above its usual height. En. gineers were of opinion that the water would soon burst its barriers, when it would rush towards Lima, sweeping every. thing before it, and submerging the lower portion of the city. Several towns in Clili had been greatly damaged by earth. quakes.

As the result of a recent careful study of the drug Pareira brawa, Mr. Daniel Hanbury has discovered that, instead of its being obtained from Cissampelos pareira, of the natural order Menispermacea, the genuine Pareira brava is the stem and root of a plant which he has identified with Chondrodendron tomentosum of Ruiz and Pavon. The drug of English com. merce, however, is mostly of larger size than the root of Chondrodendron and is of doubtful origin, the structure of the wood being also that of the order Menisfermaced.

UNDER the title of "On Coal at Home and Abroad," Messrs. Longman have recently published in one volume the following three articles, contributed to the Edinburgh Review by the Rev. J. R. Leifchild :-1. Consumption and Cost of Coal; 2. On the Coalfields of North America and Great Britain ; 3.Fatal Accidents in Coal Mines. The republication of these papers at the present time is very opportune; they will be found to contain a great deal of information on the all-important "Coal question," as well as many interesting details concerning the working of coal mines and the characier and condition of the miners.

Zootogists will find in Dr. Theodore Gill's "Synoptical Tables of Characters of the Mammalia," prepared for the Smithsonian Institution of Washington, an excellent, concise, and accurate description of the characters of the families of the Mammalia, in a form more scientific and manageable than any yet published, at the same time that the merits of the most modern suggestions are fully weighed. The biography of the subject is also exhaustively treated.

Tue Brighton Aquarium is an institution which all biologists undoubtedly look to as one from which much valuable in. formation may be obtained on points connected with the habits and peculiarities of the animals which it has such advantages in retaining. The communications made public by its "Consulting Naturalist," however, are of a character very different from what we should expect.from one so favourably placed. A fresh arrival is thus announced:- " One, of the funniest little "cusses'. ever turned out of Nature's workshop, in the shape of a seal, made $a$ bow to the public in the Irighton Aquarium;a few days ago." This is followed, later on, by a quasi advertisement of the concert given in the building, in which the seal is playfully made to do duty as the butt for pun and slang quotation.

THE additions to the Zoological Society's Gardens during the past week include two Persian Sheep (Ovis aries), presented by Mr. W. H. Shirley; a Diamond Snake (Mforclia spilotes) from New South Wales, presented by Mr. H. Frieland ; two Robben Island Snakes (Coronella phocarum), presented by the Rev. G. H. Fisk; two Chubb (Lewciscus cephalus) and a Barbel (Barbus vulgaris) presented by Mr. E. S. Wilson; two Ring-tailed Lemurs (Lemur calta) from Madagascar; a King Parakeet (Aprosmictus scâ̧ulatus) from New South Walez; a Black Cuckoo (Eudynamys orientalis) from India, purchased; a Weeper Capuchin (Cebus capucinus and a White-throated Sa. pajou ( $C$. hysolewcus) from America, deposited.

\section{A POSSIBLE NEW METHOD OF ELECTRICAL ILLUMINATION}

$\mathrm{I}^{\mathrm{T}}$ will be in the recollection of the readers of the Fournal that, in April last, an analogy was pointed out between sunlight and the electric light, and that certain conditions were therein indicated as being most favourable to that particular de velopment of light which would best bring out the separation of the power producing the light from the place of its manifesta. tion. Those conditions were the employment of magneto-elec. tricity, and the use of a closed incandescent conductor in an atmosphere which would not oxidise or otherwise affect the dura. bility of the light-producing material. From the quotation from the Russian paper Golos which follows, it will be seen that the results anticipated are even now in the course of realisation, and all that practical men can do is, to wish the plan the success it scems to deserve, and to wait the result of the further exhibitions of its power in London and other places more accessible to the Western nations than St. Petersburg :-

"On Tuesday the 8-20 of May, a most interesting trial was made for the first time in public at the Admiralty House, $\mathrm{St}$ Petersburg, under the auspices of Messrs. S. A. Kosloff and Co., the proprietors of the patent, of a new system of light. ing by electricity, the invention of Mr. A. Ladiguin, of that town.

"Owing to the restricted space in the hall made use of on this occasion, the number of spectators was necessarily limited, but still they consisted of more than a hundred specialists from different countries, representatives of science, honourable visitors, and many reporters, who were all deeply interested, and unani. mously decided that the trial was really successful.

"Up to the present time, as is well known, the electric light has been used only for lighthouses, as an electric sun illumina. tion for signals, or on the stage, where a strong light may be required without regard to cost; but thus far it has been quite impossible to employ it for lighting streets or houses.

"By the old method the electric spark was passed between two points of charcoal, each attached to a copper wire connected
with anelectro-magnetic machine.

"The disadvantages attending this mode consisted in the facts that, for each light a separate machine was required, and that the [light so obtained, although very powerful, was im. possible to be regulated, besides being non-continuous, owing to the rapid consumption of the charcoal points from exposure to air.

"All these difficulties Mr. A. Ladiguin has tried and appa. rently overcome most successfully.

"By his newly-invented method, only one piece of charcoal or other bad conductor is required, which being attached to a wire connected with an electro-magnetic machine is placed in a glass tube, from which the air is exbausted, and replaced by a gas which will not at a high temperature combine chemically with the charcoal. This tube is then hermetically sealed, and the machine being set in motion by means of a small steam. engine, the charcoal becomes gradually and equally heated, and emits a soft, steady, and continuous light, which, by a most simple contrivance, can be strengthered or weakened at the option of those employing it; its duration being dependent solely on the electric current, which of course will last as long as the machine is kept in motion.

"Taking into consideration the fact that one machine, worked by a small three-horse power engine, is capable of lighting many hundreds of lanterns, it is evident what an enormous advantage and profit could be gained by the illumination of streets, private houses, public buildings, and mines with the new electric light. In the latter it must prove invaluable, as no explosion need ever be feared from it, and these lanterns will burn equally as well
under water as in a room.

"Without mentioning the many advantages this mode of illumination has over gas, which by its unpleasant odour and evaporation is slowly poisoning thousands of human beings, and from which explosions are frequent, we can state that by calculations made, this electric light can be protuced at a fifth of the cost of coal gas.

"We hope shortly to place before the public more complete particulars, as well as reports of further experiments which are
proposed to take place in Vienna, Paris, and London.'

* From the Fournal of the Socicty of Arts. 